\section{Comparative studies to model bioavailability of pesticides in distinctive soil types}

\author{
Diána Virág - Attila Kiss \\ EGERFOOD Regional Academic Knowledge Centre \\ Eszterházy Károly College, Eger \\ viragdia@ektf.hu
}

\begin{abstract}
SUMMARY
Bioavailability of pesticides is determined by two major factors: soil characteristics and pesticides' chemical feature. These factors result in a definite adsorption capability whose extent varies on a large scale. By revealing interactions between pesticides and soils it is of high interest to model bioavailability of widely used pesticides, as it is a key element in terms of prospective toxicological aspects. Our work signifies steps forward improving pesticide soil mobility prediction models as we created model systems representing correctly natural relations. Comparison of different solvent extraction methods proved to be an efficient tool to gain information on the bioavailability of some widely used pesticides as well as to model actual environmental processes.

Comprehensive comparison has been made between different experimental methods by applying 5 extraction models showing diverse efficiency in extracting capability of pesticides. In some cases chloroform excelled in mobilizing pesticides from soil, however mostly application of humic acid solution as extraction model was found to be at least as efficient as methanol, chloroform or $\mathrm{CaCl}_{2}$-solution.

Four chemically much different pesticide (simazine, acetochlor, chlorpyrifos and diuron) were applied to two soil types (both sandy and brown forest). The extracted amounts were determined by GC/MS technique. Adsorption coefficients $\left(K_{d}\right)$ were also calculated for the examined samples.

Obtained results for $K_{d}$ indicated that chemical feature of pesticides seemed to be of utmost importance in terms of soil binding capability preceding the relevance of soil characteristics. Adsorption capability of chlorpyrifos proved to be the most pronounced preceding simazine and the least prone to bind to soil acetochlor and diuron.
\end{abstract}

Keywords: pesticides, bioavailability, extraction models, pesticide soil interaction

\section{INTRODUCTION}

Chemical components being present in environmental subregions are available for organisms to various extent thus they have diverse effect on ecosystems. The chemical waste in soil, sediment, and water may influence, or even regulate, bioremediation efficiency (Southgate et al., 1989). Bioavailability can be defined as the amount of present contaminant that can be degraded and readily taken up by microorganisms (Maier, 2000). The characterization of pesticide bioavailability, particularly in aged soils, could be important to be taken into consideration because this information is necessary for environmental risk assessment (Regitano et al., 2006).
To establish chemical extraction procedures for predicting bioavailability of butachlor and myclobutanil in soil, several solvent systems (methanol, methanol-water (9:1), methanol-water $(1: 1)$, acetone-water $(5: 3)$, petroleum ether and water) were assessed to determine the extractability of the target compounds from soil samples (Yu et al., 2005). According to their experimental data these extraction procedures may be efficient for predicting bioavailability of the two pesticides studied.

Behaviour of $\left[{ }^{14} \mathrm{C}\right]$-hydroxy-simazine in luvisol soil was examined to estimate its residues at different incubation time (Kloskowski et al., 1985). 62 days after beginning the fulvic acid and humin fractions contained up to $85 \%$ of the labelled ring carbon applied.

Aged and bound herbicide residues in soil and their bioavailability were studied (Kloskowski et al., 1987) by applying [Carbonyl $-{ }^{14} \mathrm{C}$ ]methabenzthiazuron to growing winter wheat. 0.01 $\mathrm{M} \mathrm{CaCl}_{2}$ solution and organic solvents were used for the extractions. About $20 \%$ of the radioactive parent compound was found in the leaves and residues of pesticide were detected from the soil.

Influence of soil aging on sorption and bioavailability of simazine was studied by Regitano et al. (2006). Solvent extraction methods were applied to correlate simazine residue bioavailability in aged soils to simazine mineralization using a simazine-mineralizing bacterium. Soil samples were treated with UL-ring-labeled $\left[{ }^{14} \mathrm{C}\right]$ simazine and extracted with $0.01 \mathrm{M} \mathrm{CaCl}_{2}$, or extracted with aqueous methanol (80:20 v/v methanol/water). 0.01 $\mathrm{M} \mathrm{CaCl}_{2} /$ methanol solution proved to be suitable for estimation bioavailable residues of simazine in aged soils.

The leaching of diuron and oryzalin through undisturbed soil columns was studied in the laboratory using three vineyard soils (rendosol,calcosol, vegetated calcosol) by Landry et al. (2004). After $845 \mathrm{~mm}$ of stimulated rainfall in 15 days, liquid samples contained higher amounts of diuron than oryzalin. The differences in mobility between soil types seem to be related to the OC distribution in the profiles; whereas, differences in diuron mobility are correlated with both OC content and soil structure.

In case of acetochlor desorption studies were performed by $\mathrm{Ma}$ et al. (2004) and Taylor et al. (2004) to determine the sorption and desorption potential of surface and subsurface soils. It is necessary to estimate the rate of acetochlor's movement to groundwater, as it might be regarded as 
a factor influencing significantly bioavailability of acetochlor as well.

Laboratory studies were conducted by NemethKonda et al. (2002) to determine the sorption behaviour of six commonly used pesticides (including acetochlor). The sorption isotherms and the octanol-water partition coefficients $\left(\mathrm{P}_{\text {ow }}\right)$ have been described. The adsorption constant showed relation to soil organic carbon content $\left(\mathrm{K}_{\mathrm{oc}}\right)$. It was concluded that the Freundlich adsorption constants $\left(\mathrm{K}_{\mathrm{f}}\right)$ were slightly related to the octanol-water partition coefficients of investigated chemicals.

There are many studies about the relation of the degradation of pesticides and the soil parameters. A number of indexing methods have been developed that aim to rank the pesticides according to the risk of leaching to the groundwater from few parameters for each substances (Fomsgaard, 2004). E.g. the GUSindex ranks the pesticides solely according to inherent properties, degradability (measured as DT50-values), and sorption (measured as $\mathrm{K}_{\mathrm{OC}}$ ) and in this way provides a measure of the potential of leaching. Lindhardt et al. (1997) showed that a ranking according to the GUS-index with a starting point in the DT50 and $\mathrm{K}_{\mathrm{OC}}$-values of 12 pesticides that had been reported to the Danish Environmental Protection Agency.

Pesticide soil/solution distribution coefficients $\left(\mathrm{K}_{\mathrm{d}}\right.$ values) are generally used parameters to predict the mobility of each pesticide in soils. In many cases soil characteristics, including the soil series name, taxonomic name, particle-size distribution or texture,
$\%$ organic matter $(\mathrm{OM})$ content, and soil solution $\mathrm{pH}$ are normally included. These $\mathrm{K}_{\mathrm{d}}$ values and soil property values are involved in many pesticide data bases and used in computer models (Carsel et al., 1984; Davis et al., 1990).

Our major objective was to create model systems representing correctly natural relations in order to characterize comprehensively pesticide soil interactions. Comparison of different solvent extraction methods proved to be an efficient tool to gain information on the bioavailability of some widely used pesticides as well as to model actual environmental processes.

Apart from the abovementioned goals we also aimed at correlating reported pesticide $\mathrm{K}_{\mathrm{d}}$ values with found soil properties in order to develop equations which would more accurately estimate $\mathrm{K}_{\mathrm{d}}$ values reflecting actual soil parameters, so as to improve pesticide soil mobility prediction models.

\section{MATERIALS AND METHODS}

\section{Studied pesticides and soils}

The four pesticides examined (introduced in Table 2), which have diverse chemical structures and behaviour, are as follows: simazine (triazine herbicide), chlorpyrifos (organophosphate insecticide), acetochlor (acetanilide herbicide) and diuron (substituted urea herbicide). All compounds represent widely used, chemically different pesticides having diverse action mechanism.

Physical and chemical properties of soil samples

\begin{tabular}{|l|r|r|r|r|r|r|r|r|}
\hline \multicolumn{1}{|c|}{ Soil type } & \multicolumn{1}{|c|}{$\begin{array}{c}\text { Sand } \\
\mathbf{( m \% )}\end{array}$} & $\begin{array}{c}\text { Rock-flour } \\
(\mathbf{m} \%)\end{array}$ & $\begin{array}{c}\text { Mud } \\
\mathbf{( m \% )}\end{array}$ & $\begin{array}{c}\text { Clay } \\
(\mathbf{m} \%)\end{array}$ & $\mathbf{p H}$ & $\begin{array}{c}\text { Humus-content } \\
\mathbf{( \% )}\end{array}$ & $\begin{array}{c}\text { Spec. conductivity } \\
(\boldsymbol{\mu} \mathbf{s} / \mathbf{c m})\end{array}$ & $\begin{array}{c}\mathbf{H} \\
\mathbf{( \% )}\end{array}$ \\
\hline Sandy & 94.8 & 5.2 & 0.0 & 0.0 & 6.53 & 1.58 & 64.2 & 2,06 \\
\hline Brown forest soil & 6.0 & 41.0 & 31.0 & 22.0 & 7.26 & 6.60 & 111.0 & 5,94 \\
\hline
\end{tabular}

The features of the studied pesticides

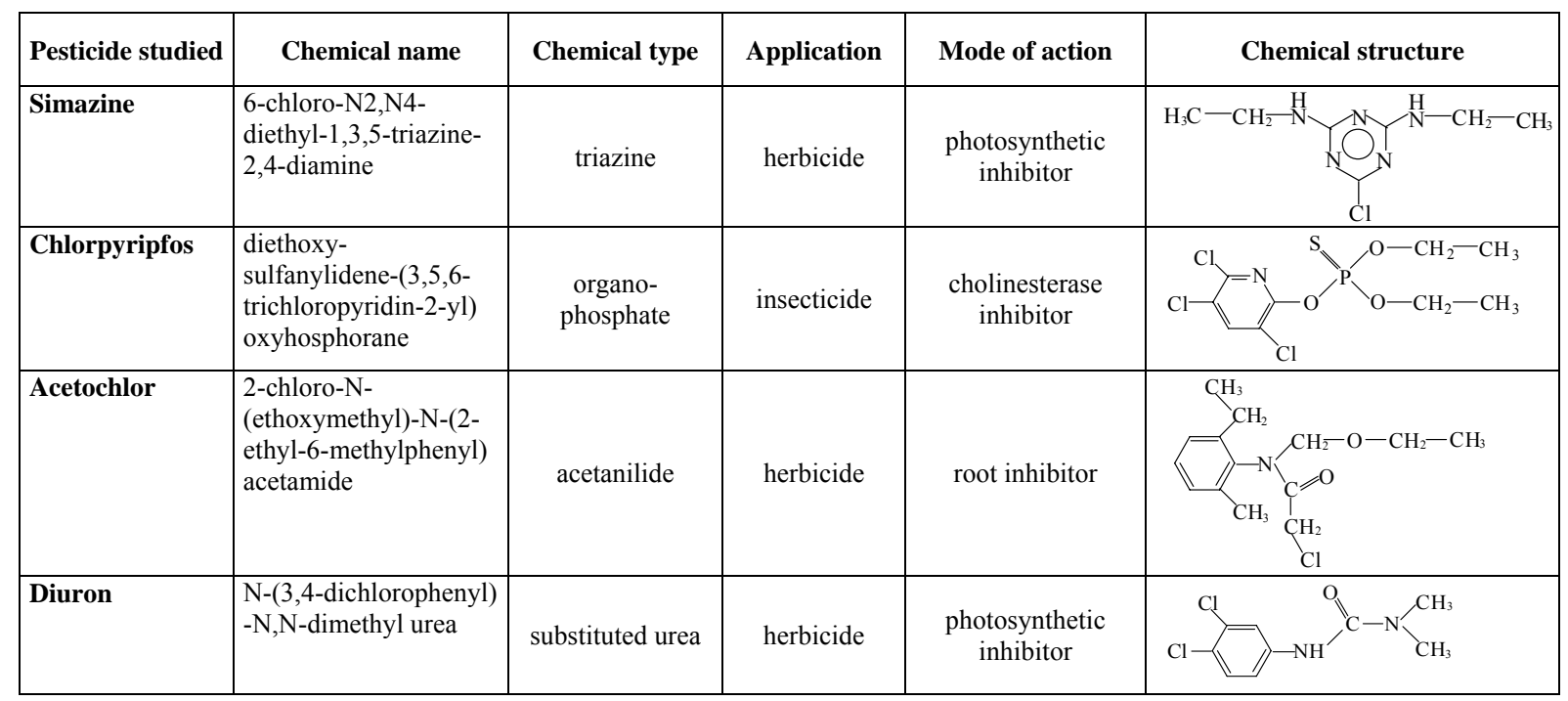


Two types of soils were chosen for the experiments, a sandy and brown forest soil. The plough layer was examined $(0-20 \mathrm{~cm})$ whose major characteristics were precisely determined (see Table 1 ) in terms of $\mathrm{pH}$, specific conductivity, humus content and granulometric composition by using traditional methods.

\section{Sample preparation}

The pesticides were dissolved in methanol, the concentration of the solutions were $200 \mathrm{ppm}$. The pesticides (higher than 99\% HPLC purity) and other applied chemicals were purchased from Aldrich. The soil samples were sieved and homogenized.

To model the bioavailable amount of pesticides according to the literary we used 5 distinctive model systems to accomplish the extraction. These extraction methods were as follows: chloroform, aqueous methanol $(80: 20 \mathrm{v} / \mathrm{v}$ methanol/water $)$, Na-acetate - acetic acid buffer ( $\mathrm{pH}=5.6), \mathrm{CaCl}_{2}$ solution $(0.01 \mathrm{M})$ and humic acid solution in two different concentration $(0.5 \mathrm{ml}$ SERA humic acid extract/1).

Throughout the sample preparation procedure three distinctive solvent volumes were applied. It was apparent (Figure 1) that application of $5 \mathrm{ml}$ solvent proved to be the most efficient in respect of achieving maximum extracted amount of pesticide, therefore it was used for further experiments.

Figure 1: Extracted amounts of simazine from brown forest soil

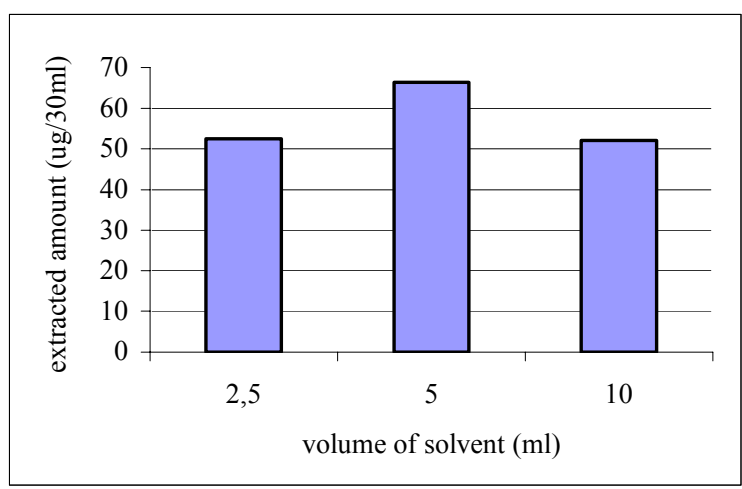

$10 \mathrm{~g}$ of each soil samples were combined with $5 \mathrm{ml}$ of each pesticide solution, so $0.1 \mathrm{mg}$ active ingredient could be attributed to $1 \mathrm{~g}$ soil. The soil samples containing pesticides have been dried at $105{ }^{\circ} \mathrm{C}$ for 2 hours, than powdered, and the same amount of them $(1 \mathrm{~g})$ were extracted with $30 \mathrm{ml}$ of the extracting solvents mentioned above for 16 hours. Then the soil samples were centrifuged at $6000 \mathrm{rpm}$ for 10 minutes and the supernatants were removed. $25 \mathrm{ml}$ of them were extracted with $15 \mathrm{ml}$ of chloroform for three minutes twice time, then evaporated in vacuo. Dry extracts were redissolved in methanol in case of simazine, acetochlor, diuron and in acetonitrile in case of chlorpyrifos.

\section{Instrumental measurements}

The extracted amounts of the basic components were detected by using GC-MS technique. The GC separations and the mass spectrometric measurements were performed by using a GC-GC/MS QP-2010S Shimadzu under the next measuring conditions: column: HP-5MS $(30 \mathrm{~m} \times 0.25$ $\mathrm{mm} \times 0.25 \mathrm{um})$, carrier gas: He $(1 \mathrm{ml} / \mathrm{min})$, detector: GC/MS QP-2010S, ionization mode: EI $(70 \mathrm{eV})$, interface temperature: $230{ }^{\circ} \mathrm{C}$, ionsource temperature: $200{ }^{\circ} \mathrm{C}$, inject volume: $1 \mu$ l. The heating parameters were the following: simazine: $110{ }^{\circ} \mathrm{C}$ (hold: $0 \mathrm{~min}) \rightarrow 240{ }^{\circ} \mathrm{C}\left(15^{\circ} \mathrm{C} / \mathrm{min}\right)$ (hold: $\left.0 \mathrm{~min}\right) \rightarrow$ $290{ }^{\circ} \mathrm{C}\left(35^{\circ} \mathrm{C} / \mathrm{min}\right)$ (hold: $\left.0,5 \mathrm{~min}\right)$; chlorpyrifos: $150{ }^{\circ} \mathrm{C}$ (hold: $\left.0 \mathrm{~min}\right) \rightarrow 290{ }^{\circ} \mathrm{C}\left(20{ }^{\circ} \mathrm{C} / \mathrm{min}\right)$ (hold: $3 \mathrm{~min}$ ); acetochlor: $80{ }^{\circ} \mathrm{C}$ (hold: $0 \mathrm{~min}$ ) $\rightarrow 280{ }^{\circ} \mathrm{C}$ $\left(15{ }^{\circ} \mathrm{C} / \mathrm{min}\right)$ (hold: $\left.0 \mathrm{~min}\right)$; diuron: $70{ }^{\circ} \mathrm{C}$ (hold: $1 \mathrm{~min}) \rightarrow 180^{\circ} \mathrm{C}\left(10{ }^{\circ} \mathrm{C} / \mathrm{min}\right)$ (hold: $\left.0 \mathrm{~min}\right) \rightarrow 220^{\circ} \mathrm{C}$ $\left(20^{\circ} \mathrm{C} / \mathrm{min}\right.$ ) (hold: $\left.0 \mathrm{~min}\right)$.

\section{Determination of $K_{d}$ and $K_{H}$ values}

The ratio of pesticide adsorbed by soil (nmole/g) and pesticide remaining in solution $(\mathrm{nmole} / \mathrm{ml})$ is the $\left(\mathrm{K}_{\mathrm{d}}\right)$. It is an indication of the sorption capacity of the chemical in case of the specified soil. $\mathrm{K}_{\mathrm{d}}$ values are generally determined for pesticide concentrations that would occur in soils when the compounds are applied at recommended extents followed by enough rainfall to bring the soil to field capacity (Weber et al., 2000).

$\mathrm{K}_{\mathrm{H}}$ values were also calculated by regarding actual humus-content of a given soil type, providing opportunity for taking one of the most important soil parameter into account.

Thus $\mathrm{K}_{d}$ values were calculated as follows:

$\mathrm{K}_{\mathrm{d}}=\left(\mathrm{C}_{\mathrm{i}}-\mathrm{C}_{\mathrm{e}}\right) / \mathrm{C}_{\mathrm{e}}$

$\mathrm{C}_{\mathrm{i}}-$ initial concentration of pesticide ( $\mu \mathrm{g} / 1 \mathrm{~g}$ soil)

$\mathrm{C}_{\mathrm{e}}$-extracted concentration of pesticide $(\mu \mathrm{g} / 1 \mathrm{~g}$ soil)

$\mathrm{K}_{\mathrm{H}}$ values were calculated in the following manner:

$\mathrm{K}_{\mathrm{H}}=\mathrm{K}_{\mathrm{d}} *(100 / \mathrm{H})_{\mathrm{H}-\text { humus-content }(\%)}$

\section{RESULTS AND DISCUSSION}

The five distinctive types of applied extracting solvents showed diverse efficiency in extracting the studied pesticides from the two different types of soil. The prompt amounts of the extracted pesticides are summarized in Table 3.

In case of the investigation of modeling the bioavailable amounts of simazine from brown forest soil the acetate buffer and the $\mathrm{CaCl}_{2}$ solution was found to be nearly as efficient as the aqueous methanol solution. In contrast to this finding Regitano et al. (2006) obtained the most amounts of simazine from soil samples by successive extractions with methanol and $\mathrm{CaCl}_{2}$ solution. Out of the aqueous extracting solvents humic acid solution proved to be the most efficient extracting solvent (producing $81.05 \%$ extraction efficiency) of the as it could be seen in Figure 3 in the comparison of GC chromatograms of the extracted amounts of simzine from sandy soil samples. 
Chloroform was the least efficient one $\mathrm{n}$ case of both soil types. The efficiency in extracting simazine from sandy soil of aqueous methanol was preceded by the natural-like extracting solvents (acetate-buffer, $\mathrm{CaCl}_{2-}$ and humic acid solutions). With acetatebuffer it was possible to extract more simazine from the soil than with $\mathrm{CaCl}_{2}$ - and humic acid solutions.

The largest amount of chlorpyrifos could be obtained with chloroform, the other extraction solvents displayed almost the same efficiency in extracting chlorpyrifos: extracted amounts were lower than $10 \%$ of the initial amount. Aqueous methanol and acetate-buffer were found to be slightly more efficient extractants than $\mathrm{CaCl}_{2}$ - and humic acid solutions, however large differences have not occurred (Figure 2).

Figure 2: Bioavailable amounts of the studied pesticides
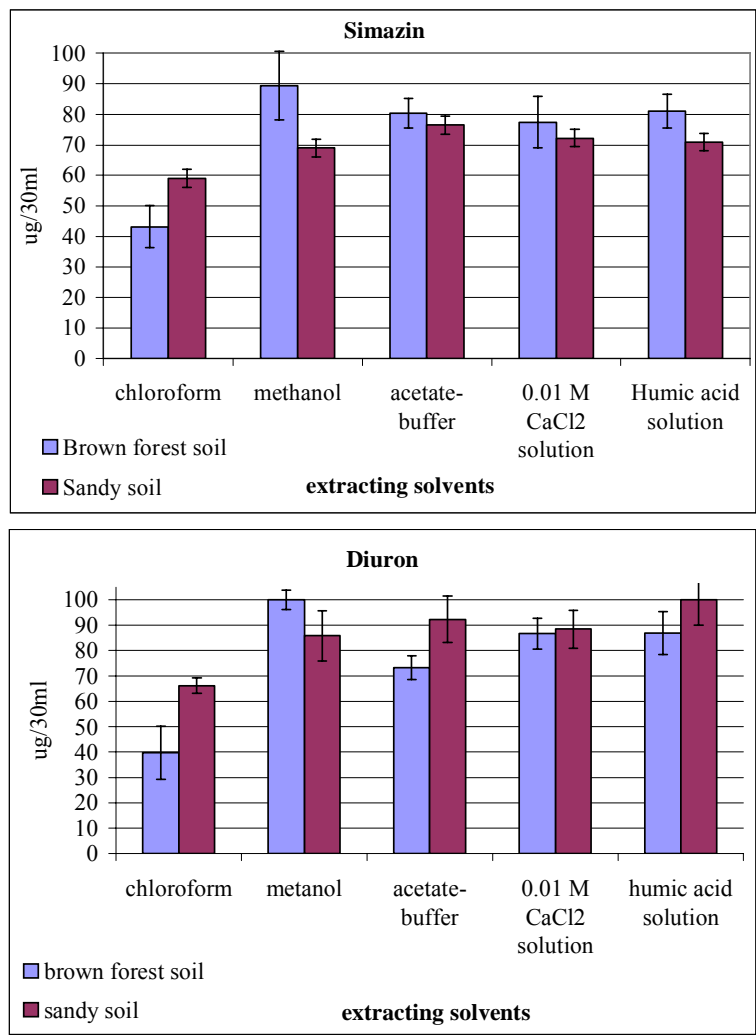

Figure 3: Comparison of GC-chromatograms of simazine samples extracted from sandy soil

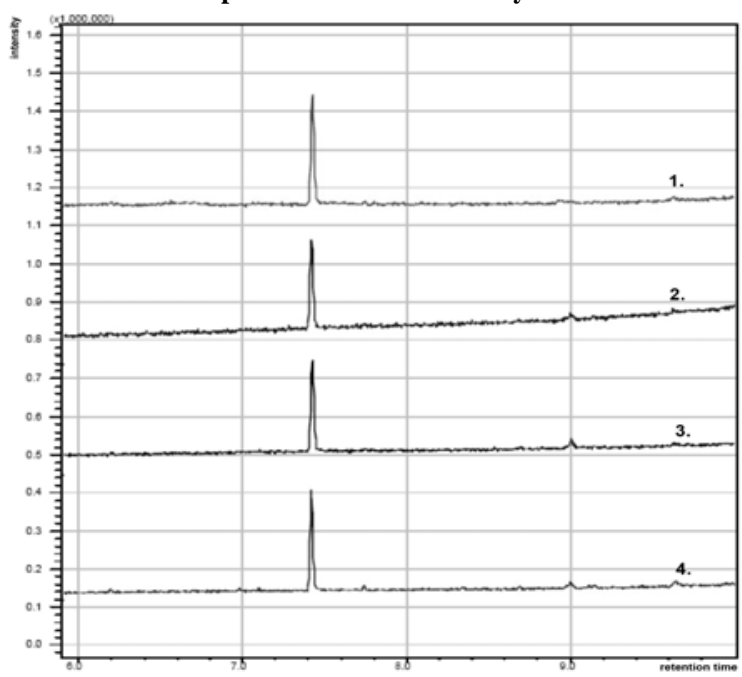

Extracting soulvents: 1. methanol, 2. humic acid solution, 3. acetate-buffer solution, $4 . \mathrm{CaCl}_{2}$-solution
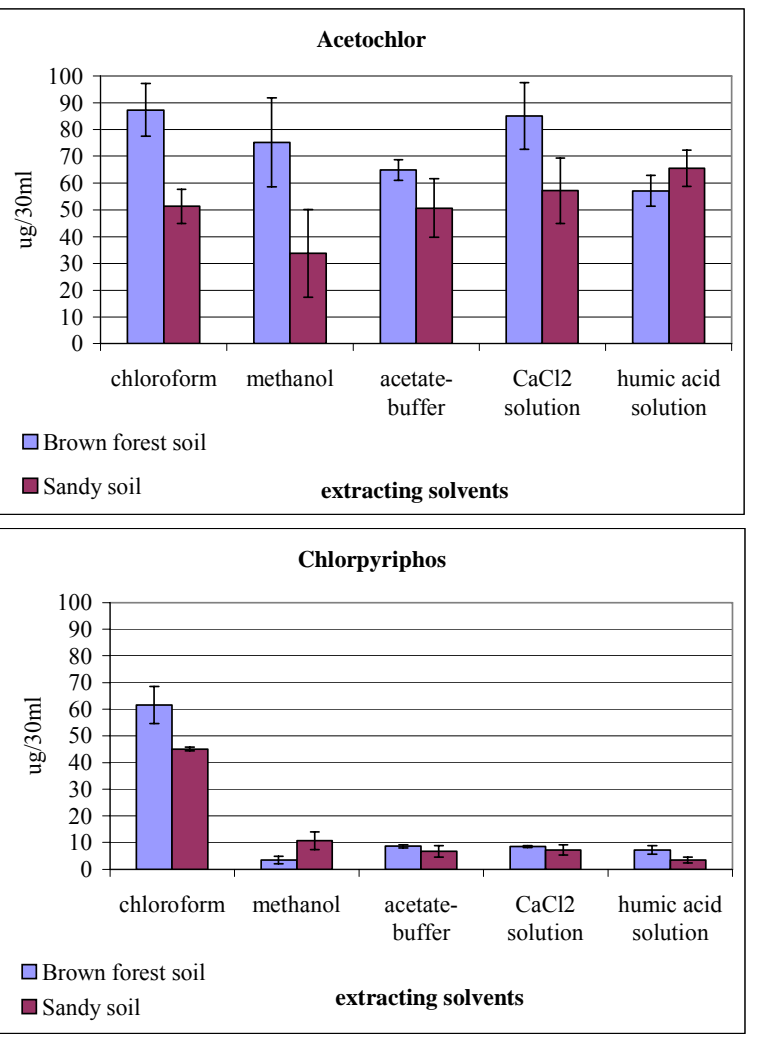

During the extracting studies larger amounts of acetochlor could be extracted from brown forest soil than from sandy soil. In case of brown forest soil $\mathrm{CaCl}_{2}$ solution was as efficient as chloroform (85\%), while with acetate-buffer and humic acid solution it was possible to extract $60 \%$ of the initial amount of acetochlor. In case of sandy soil aqueous extracting solvents were suitable to extract more acetochlor than chloroform and methanol solution.

The applied extracting solvents for diuronexcept chloroform - were really efficient: more than $80 \%$ of the diuron was extracted from both types of soils. In case of brown forest soil $\mathrm{CaCl}_{2}$ solution was found to be the most efficient extracting solvent $(86.6 \%)$, while in case of sandy soil humic acid solution excelled from the three aqueous extracting solvents by producing $100 \%$ efficiency. The noticed differences could be explained by the different organic matter content of soils, which is a determining factor in adsorption of diuron as it was pointed out in the study of Landry et al. (2004). 
Extracted amounts of the studied pesticides

\begin{tabular}{|c|c|c|c|c|c|c|}
\hline & & \multicolumn{5}{|c|}{ Extracted amounts of pesticides ( $\mu \mathrm{g} / 30 \mathrm{ml}$ extracting solvent) } \\
\hline & & chloroform & methanol & acetate-buffer & $\mathrm{CaCl}_{2}$-solution & humic acid \\
\hline \multirow[t]{2}{*}{ Simazine } & Brown forest soil & 43.19 & 89.39 & 80.43 & 77.43 & 81.05 \\
\hline & Sandy soil & 58.99 & 68.93 & 76.50 & 72.22 & 70.88 \\
\hline \multirow[t]{2}{*}{ Chlorpyrifos } & Brown forest soil & 61.56 & 3.45 & 8.52 & 8.48 & 7.14 \\
\hline & Sandy soil & 44.99 & 10.74 & 6.68 & 7.20 & 3.40 \\
\hline \multirow[t]{2}{*}{ Acetochlor } & Brown forest soil & 87.32 & 75.18 & 64.75 & 85.03 & 57.09 \\
\hline & Sandy soil & 51.32 & 33.76 & 50.66 & 57.11 & 65.46 \\
\hline \multirow[t]{2}{*}{ Diuron } & Brown forest soil & 39.68 & 96.55 & 100.00 & 73.25 & 86.63 \\
\hline & Sandy soil & 66.21 & 95.67 & 85.82 & 92.32 & 88.43 \\
\hline
\end{tabular}

Adsorption coefficients $\left(\mathrm{K}_{\mathrm{d}}\right)$ were also calculated for the examined samples. The $\mathrm{K}_{\mathrm{d}}$ values were normalized to the humus content of each soil $\left(\mathrm{K}_{\mathrm{H}}\right.$ values, Table 4). The extracted amounts of each pesticide obtained by the natural-like, aqueous solution based extracting solvents (acetate-buffer, $\mathrm{CaCl}_{2}$ - and humic acid solution) were averaged in order to acquire more simple and comprehensively comparable parameters. The lowest Kd value (1.134) was calculated in case of chlorpyrifos (sandy soil), while the highest (30.373) in case of diuron (sandy soil).

The $\mathrm{K}_{\mathrm{d}}$ values spread between 0.022 and 1124.651 showing much different binding characteristics of examined pesticides confirming the observations of Nemeth-Konda et al. (2002). Real distinction could be made between soil types in terms of adsorption capability. The chemical feature of pesticides seems to be of utmost importance in this respect preceding the relevance of soil characteristics. Much difference might be observed when comparing $\mathrm{K}_{\mathrm{d}}$ and $\mathrm{K}_{\mathrm{H}}$ values of each pesticides showing that among the examined pesticides chlorpyrifos excels in soil binding capability. Adsorption liability of simazine slightly precedes that of acetochlore and diuron. Comparison of different extraction methods led to the conclusion that each model might provide us with interpretable results, however as in most cases no major differences could be observed in $K_{d}$ data obtained by the different methods. Therefore it is sensible to regard and put more emphasis on the values referring to the aqueous solution based extracting solvents, as well as their average bearing aggregate information on soil binding capability.

$K_{d}$ and $K_{H}$-values of the studied pesticides

\begin{tabular}{|c|c|c|c|c|c|c|c|c|c|c|c|}
\hline \multicolumn{2}{|c|}{ Extracting solvents } & \multicolumn{2}{|c|}{ chloroform } & \multicolumn{2}{|c|}{ methanol } & \multicolumn{2}{|c|}{ acetate buffer solution } & \multicolumn{2}{|c|}{$\mathrm{CaCl}_{2}$-solution } & \multicolumn{2}{|c|}{ humic acid solution } \\
\hline & Soil type & $\mathbf{K}_{\mathbf{d}}$ & $\mathbf{K}_{\mathbf{H}}$ & $\mathbf{K}_{\mathbf{d}}$ & $\mathbf{K}_{\mathbf{H}}$ & $\mathbf{K}_{\mathbf{d}}$ & $\mathbf{K}_{\mathbf{H}}$ & $\mathbf{K}_{\mathbf{d}}$ & $\mathbf{K}_{\mathbf{H}}$ & $\mathbf{K}_{\mathbf{d}}$ & $\mathbf{K}_{\mathbf{H}}$ \\
\hline \multirow{3}{*}{ 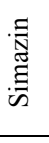 } & Brown forest & 1.316 & 22.155 & 0.119 & 2.003 & 0.243 & 4.091 & 0.292 & 4.916 & 0.234 & 3.939 \\
\hline & Sandy & 0.695 & 33.738 & 0.451 & 21.893 & 0.307 & 14.903 & 0.385 & 18.689 & 0.411 & 19.951 \\
\hline & Alluvial & 0.413 & 11.090 & 0.006 & 0.161 & 0.139 & 3.733 & 0.166 & 4.458 & 0.096 & 2.578 \\
\hline \multirow{3}{*}{ 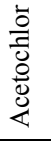 } & Brown forest & 0.145 & 2.441 & 0.330 & 5.556 & 0.544 & 9.158 & 0.176 & 2.963 & 0.751 & 12.643 \\
\hline & Sandy & 0.949 & 46.068 & 1.962 & 95.243 & 0.974 & 47.282 & 0.751 & 36.456 & 0.528 & 25.631 \\
\hline & Alluvial & 1.044 & 28.034 & 1.053 & 28.276 & 0.283 & 7.599 & 0.234 & 6.284 & 0.359 & 9.640 \\
\hline \multirow{3}{*}{ 泀 } & Brown forest & 0.774 & 13.030 & 0.076 & 1.279 & 0.322 & 5.421 & 0.412 & 6.936 & 0.330 & 5.556 \\
\hline & Sandy & 0.277 & 13.447 & 0.234 & 11.359 & 0.022 & 1.068 & 0.344 & 16.699 & 0.097 & 4.709 \\
\hline & Alluvial & 0.343 & 9.211 & 0.158 & 4.243 & 0.559 & 15.011 & 0.444 & 11.923 & 0.361 & 9.694 \\
\hline \multirow{3}{*}{ 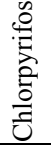 } & Brown forest & 0.624 & 10.505 & 27.952 & 470.572 & 10.734 & 180.707 & 10.794 & 181.717 & 13.002 & 218.889 \\
\hline & Sandy & 1.223 & 59.369 & 8.314 & 403.592 & 13.977 & 678.495 & 12.883 & 625.388 & 28.394 & 1378.350 \\
\hline & Alluvial & 0.797 & 21.402 & 41.882 & 1124.651 & 164.84 & 4426.343 & 167.070 & 4486.224 & 153.080 & 4110.714 \\
\hline
\end{tabular}

When comparing the extractable amounts of pesticides, it is obvious that the applied solvents showed different extraction capability in terms of different pesticides and the two studied types of soil (Figure 4). In case of simazine, chlorpyrifos and diuron the methanol and the aqueous extracting solvents exhibited nearly the same efficiency in extracting pesticides from both soil types. When comparing the acquired amounts of extracted pesticides in case of the studied two soil types, nearly analogous tendency might be observed, as negligible amounts of chlorpyrifos was yielded, while the applied solvents proved to be the most efficient extracting agents to gain diuron. In general the aqueous extracting solvents (acetate-buffer, $\mathrm{CaCl}_{2}$ and humic acid solution) extracted more pesticide 
than chloroform and methanol. Methanol solution proved to be the most efficient in extracting chlorpyrifos from sandy soil, while in case of brown forest soil the aqueous extracting solvents were more effective than methanol. In case of acetochlor the results were different from the above mentioned pesticides: methanol and the aqueous extracting solvents showed the same efficiency in case of brown forest soil, while in case of sandy soil the aqueous extracting solvents were found to be much more efficient.

Figure 4: Comparison of the extractable amounts of the studied pesticides

The methanol extractable amount of the studied pesticides

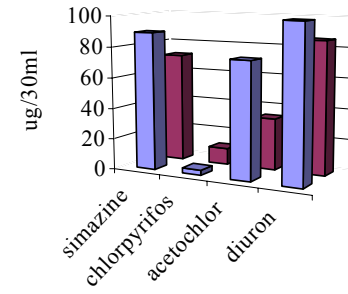

$\square$ brown forest soil $\square$ sandy soil

\section{CONCLUDING REMARKS}

Investigation of different solvent extraction methods in order to model pesticide-soil interactions proved to be an efficient tool to obtain precise data on soil-binding capabilities of some widely used pesticides. Thus we gained insight into the bioavailability of these important soil contaminants, as well as created models to describe actual environmental processes.

Obtained results for $\mathrm{K}_{\mathrm{d}}$ indicated that chemical feature of pesticides seemed to be of utmost importance in terms of soil binding capability preceding the relevance of soil characteristics. Reported pesticide $\mathrm{K}_{\mathrm{d}}$ values showed much different binding characteristics of examined pesticides contributing to proper understanding of pesticide soil mobility prediction models. Chlorpyrifos excels in
The average of the extracted amounts of the studied pesticides by the aqueous extracting solvents (buffer, $\mathrm{CaCl}_{2}$, humic acid)

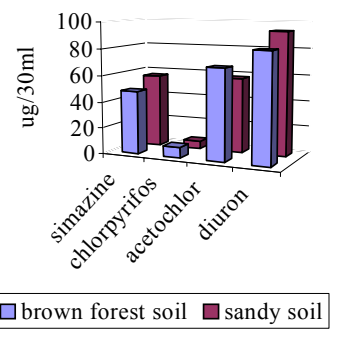

soil binding capability preceding simazine, acetochlore and diuron.

The five distinctive types of applied extracting solvents displayed different effectivity for mobilizing pesticides from soil. In most cases application of humic acid solution as extraction model was found to be at least as efficient as methanol or chloroform solution proved to be the most efficient extracting solvent. The developed model system applying natural-like extracting solvents like buffer solution, $\mathrm{CaCl}_{2}$ solution or humic acid solution is an efficient tool to estimate the bioavailable amount of pesticides, besides having no environmental risks in contrast to the frequently applied previously introduced methods (Kloskowski et al., 1987; Regitano et al., 2006; Yu et al., 2005) based on organic solvents.

\section{REFERENCES}

Carsel, R. F.-Smith, C. N.-Milch, L. A.-Dean, J. D.-Galius, P. (1984): Users Manual for the Pesticide Root Zone Model (PRZM). US Environmental Protection Agency, Athens, GA.

Davis, F. M.-Leonard, R. F.-Knisel, W. G. (1990): Gleams User Manual, US Department of Agriculture. Agricultural Research Service, Southeast Watershed Research Laboratory, Tifton, GA.

Fomsgaard, I. S. (2004): The Influence of Sorption on the Degradation of Pesticides and other Chemicals in Soil. Danish Institute of Agricultural Sciences

Kloskowski, R.-Führ, F. (1985): Behaviour of [ring-14C] hydroxysimazine in a parabraun soil. Chemosphere, 14. 11-12. 19131920.

Kloskowski, R.-Fuhr, F. (1987): Aged and bound herbicide residues in soil and their bioavailability. Part 2: Uptake of aged and non-extractable (bound) [carbonyl-14C] methabenzthiazuron residues by maize. J Environ Sci Health B. 22(6):623-42.
Landry, D.-Dousset, S.-Andreux, F. (2004): Laboratory leaching studies of oryzalin and diuron through three undisturbed vineyard soil columns. Chemosphere 54. 735-742

Lindhardt, B.-Fomosgaard, I. S.-Brüsch, W.-Bossi, R. (1997): Pesticiders udvaskelighed - vurdering af usikkerheden på DT50 og K $\mathrm{OC}_{\mathrm{OC}}$ der anvendes i GUS. GEUS rapport. Sept. 1997.

Ma, Q. L.-Rahman, A.-James, T. K.-Holland, P. T.-Mcnaughton, D. E.-Rojas, K. W.-Ahuja, L. R. (2004): Modeling the Fate of Acetochlor and Terbuthylazine in the Field Using the Root Zone Water Quality Model. Soil Science Society Of America Journal.68.1491-1500.

Maier, R. (2000): Bioavailability and its importance to bioremediation. In: Valdes, J. J. (ed.). International Society for Environmental Biotechnology: Environmental Monitoring and Biodiagnostics. Kluwer Academic Publishers, 59-78.

Nemeth-Konda, L.-Füleky, Gy.-Morovjan, Gy.-Csokan, P. (2002): Sorption behaviour of acetochlor, atrazine, carbendazim, diazinon, imidacloprid and isoproturon on Hungarian agricultural soil. Chemosphere 48. 5. 545-552. 
Regitano, J. B.-Koskinen, W. C.-Sadowsky, M. J. (2006): Influence of Soil Aging on Sorption and Bioavailability of Simazine. J Agric Food Chem. 22;54(4):1373-1379.

Southgate, D.-Johnson, I.-Fenwick, G. R. (1989): Nutrient Availability: Chemical and Biological Aspects. Royal Society of Chemistry, Cambridge, UK.

Taylor, J. P.-Mills, M. S.-Burns, R. G. (2004): Sorption and desorption behaviour of acetochlor in surface, subsurface and size-fractionated soil. European Journal of Soil Science, 55. 671-679.
Weber, J. B.-Wilkerson, G. G.-Linker, H. M.-Wilcut, J. W.-Leidy, R. B.-Senseman, S.-Witt, W. W.-Barrett, M.-Vencil, W. K., Shaw, D. R.-Mueller, T. C.-Miller, D. K.-Brecke, B. J.Talbert, R. E.-Peeper, T. F. (2000): A proposal to standardize soil/solution herbicide distribution coefficients. Weed Sci. 48, $75-88$.

Yu, Y. L.-Wu, X. M.-Li, S. N.-Fang, H.-Tan, Y. J.-Yu, J. Q. (2005): Bioavailability of butachlor and myclobutanil residues in soil to earthworms. Chemosphere, 59. 7. 961-967. 